\title{
7. ADVOCATING THE POETICS OF SOUND IN THE CYCLE LES NUITS D'ÉTÉ BY HECTOR BERLIOZ
}

\section{Loredana Viorica Iațeșen ${ }^{52}$}

\begin{abstract}
By consulting monographies, musicological studies, specialty articles about the personality of romantic musician Hector Berlioz and implicitly linked to the relevance of his significant opera, one discovers researchers' constant preoccupation for historical, stylistic, analytical, hermeneutical comments upon aspects related to established scores (the Fantastic, Harold in Italy symphonies, dramatic legend The Damnation of Faust, dramatic symphony Romeo and Juliet, the Requiem, etc.). Out of his compositions, it is remarkable that the cycle Les nuits d'été was rarely approached from a musicological point of view, despite the fact that it is an important opus, which inaugurates the genre of the orchestral lied at the end of the $19^{\text {th }}$ century and the beginning of last century. In this study, we set out to compose as complete as possible an image of this work, both from an analytic-stylistic point of view by stressing the text-sound correspondences and, above all, from the perspective of its reception at a didactic level, by promoting the score in the framework of listening sessions commented upon as part of the discipline of the history of music. In what follows, I shall argue that the cycle of orchestral lieder Les nuits d'été by Hector Berlioz represents a work of equal importance to established opera.
\end{abstract}

Key words: romantic composer, orchestral lied, text-sound relationship, critical reception

\section{Introduction}

\subsection{Les Nuits d'été, Possible Meanings of the Title}

Unlike other works by Hector Berlioz, there is little documentary information about this ensemble of six poems on music entitled Les Nuits d'été, on the lyrics of Théophile Gautier. There is no such information either in the composer's well-known Memoirs, or in his correspondence, as there is no piece of contemporary criticism about it. The only sources of information and documentation are the different editions of the musical score and especially the references to the personalities of the musicians to whom they were dedicated. Therefore, its subsequent reception makes it difficult to analyze the meanings and the significances of this opus. It is only natural to ask ourselves today whether this work, which escapes the grandiose life of Berlioz, who was at the same time composer, concert organizer, musical critic and librettist, could not be a more special way to his heart, to his most intimate thoughts. In other words, this composition invites us to address the source of inspiration of the opus, most often masked behind a musician appreciated mainly for the force of his orchestration. A work that was long considered minor in the evolution of an exceptional career of the nineteenth-century romantic musician Hector Berlioz, who was recognized by his ostentatiously displayed grandiloquence. This was the beginning of a piece of criticism Enquête sur un titre published in 2015 by Élisabeth Brisson in an online pedagogical journal. The quoted piece is part of a

\footnotetext{
52 Associate Professor PhD., "George Enescu" National University of Arts from Iaşi, Romania, email: iatesenloredana@yahoo.com
} 
wide exegesis (monographs, volumes of studies, reviews, essays signed by professional musicians or music lovers, men of letters), which was built around the preoccupations of the emblematic figure of artist Hector Berlioz.

\section{Mistery of the silence surrounding a valuable opus.}

\subsection{Possible explanations depending on the manner of reception}

The first publication of the first version of the Les Nuits d'été score for voice and piano opus 7 ( $\mathrm{H} 81 \mathrm{~A}$ ) dates back to 1841 and it is the work of Adolphe Catelin, an editor with whom Berlioz cooperated between 1838 and 1843. Between 1837 and 1843, he also edited six other opuses by Hector Berlioz, which were republished in 1843 by another important editor of that time, Simon Richault, and who also handled the publication of the second edition, only for voice and piano (H 81 A) in 1855.

In the Les Nuits d'été cycle or collection study (Rushton, 2016, pp. 112135), musicologist Julian Rushton argues whether the group of melodies published by Berlioz as Les Nuits "constitutes a collection of melodies belonging to a poet and composer, or it should be called a cycle, with all that this term implies for our understanding it as a whole" (Rushton, 2016, p. 112). Moreover, the researcher debates extensively on the two distinct versions of the musical score: the first, composed in 1840 and published the following year, is for voice and piano, whereas the second, the orchestration of which was performed at different times, was published in 1856 for voice and orchestra. "Although in 1841 the arias were designed for mezzo-soprano or tenor, with the exception of the $5^{\text {th }}$ aria, which is for tenor, in 1856, in order to be suitable for the performers to whom they were dedicated, Berlioz transposed the second and third arias at different times and indicated a preference for male voices for the second and penultimate arias" (Rushton, 2016, p. 112). The same author questions the timbre parameter that is different in each aria. "Although Berlioz expressed his preference for the publication of all six arias in a single cycle, his compositional conception suggests little concern for a cyclical vision", argues the musicologist in the quoted study (Rushton, 2016, p. 113).

Surprisingly enough, in another study, In the shadows of Les Nuits d'été, (Bloom, 2016, pp. 80-111), comprising six sections, (1. the issue of the year of creation of the Les Nuits d'éte cycle; 2 . the appearance of the autographs on the manuscripts; 3. the relationship between Berlioz and Théophile Gautier; 4. and 5. the review of the cycle and of Berlioz's inner motivation when conceiving the music; 6. the analysis of the third aria of the cycle, Sur les lagunes, in an attempt to build what Berlioz would have called admiring criticism), musicologist Peter Bloom believes that "the work may be considered a cycle - i.e., a group of musical pieces that unfold logically in terms of both poetic discourse, and musical continuity" (Bloom, 2016, p.83).

In order to understand the options of the two musicologists as concerns the performance of the opus as a cycle or as a collection of arias, some clarifications are required regarding the biography of the composer, which determined or influenced the writing of this work. So, just how well known was 
Hector Berlioz in the music world in 1841? Born in Côte-Saint-André, close to Grenoble, in 1803, he moved to Paris in 1821, where, during his medical studies, he got enthusiastic about Gluck's Iphigénie en Tauride opera and decided to embrace a musical career. Thus, in 1841, Berlioz had already composed a significant number of works: four symphonies, an opera, overtures, several melodies. Moreover, a performance of the Fantastic Symphony conducted by Antoine Habeneck took place in the Conservatory venue on 5 December 1830. Another performance took place during the official events of the Grande Messe des morts Requiem (1837), then the Funeral and Triumphal Symphony for chorus and orchestra (1840), these works being performed during public and private concerts, most of which were organized by himself. It is worth noting that in 1841 Berlioz was a very visible composer.

In the light of this information, it is clear that during the composition of the six arias that we focus on, "the destiny of the musician Berlioz was fulfilled in his career as a composer, a surprising artist who, although he never demonstrated any interpretative skills (he did not play the piano, but he got a little familiar with playing the flute or the guitar), was very fond of literature: impressed by W. Shakespeare, then by W. Goethe's Faust, he translated from Gérard de Nerval at the end of 1827 and became a close friend of V. Hugo and Théophile Gautier. In 1835, in the Le Temps magazine, it was Joseph d'Ortigue, the musical critic, who had already published a biography of Berlioz in the Revue européenne in December 1832, insisting on his triple filiation: Shakespeare, Beethoven and Hugo, that claimed he was the musical counterpart of the poet Victor Hugo (Brisson, 2015, p. 2). Let us not forget that the programmatic vocal-symphonic works completed before 1840 proved the important role that literature played for him.

"Therefore, interested in various readings, Berlioz published numerous pages of musical criticism. We refer to his numerous reviews written between 1835 and 1863, as well as the musical criticism page he wrote in the Journal des Débats; to the memoirs written between 1838 and 1863 . He is also the author of several programs and librettos, starting with the Fantastical Symphony, followed by Lélio, and continuing with the Damnation of Faust (1846), a very free adaptation of his source (Goethe's Faust), then Béatrice et Bénédict (1860), Troyens (1861), and the through and close work with his librettists, Léon de Wailly and Henri Auguste Barbier, for the Benvenuto Cellini opera of 1838" (Brisson, 2015, p. 3). Coming back to the documented study by Julian Rushton, Les Nuits d'été: cycle or collection?, we cannot help but noting the interesting debate on the themes of the melodies, a debate in which the author commented in general the poetical phrases in Gautier's text in a special aesthetic-analytical manner.

\section{Les Nuits d'été. Poetical phrases}

In Berlioz's six lieds included in the Les Nuits d'été cycle, "one finds different key words defining the emotional state that must transcend at the moment of the interpretative act: the overwhelming brightness that dominates 
the first and last arias, Vilanelle and L'Île Inconnue, the languorous sensuality of Le Spectre de la rose, the inconsolable expectation of the Absence, the dark affliction of the Sur les lagunes, or the sense of the dreamy specter in $\mathrm{Au}$ cimitière" (Rushton, 2016, p. 112). At first glance, the author comments on the composer's choice of the subject in Les Nuits d'ete, there is no "actual narrative, as the musician is not concerned with identifying the poetic character of a poem with another's. Carnal love is the predominant theme of Théophile Gautier's collection La comedie de la mort. Nevertheless, even if we assume the existence of a male protagonist (despite Berlioz's choice of the type of voice), he and his lover are constantly transforming.

For example, in the two arias, with the subtitle Lamento, the main characters are a fisherman headed towards the unlimited ocean (no. 3) and a neurotic claustrophobic amateur in a church (no.5). The first and second melodies reveal two lovers who cannot be identified with each other, and in the fourth song, one of the two protagonists of the possible couple is absent. We find surprising the poetic idea of the second lied, where the singer character is nothing but a dead rose. It would seem that Berlioz chose these poems less for their narrative coherence, but especially for the sake of musical contrast. Indeed, one of the most remarkable aspects of the cycle is the variety achieved in the central sequence of four slow melodies. If we feel the presence of a narrative element, it becomes possible with the help of metaphor" (Rushton, 2016, pp. 113-114). In an attempt to imagine the compulsory use of this opus in the subject of music history, with the audition accompanied by general observations on the musical score, we have devised a general route of the parity-sonority commentary, starting from the importance of approaching the genre in an innovative manner by Hector Berlioz.

\section{Les Nuits d'été cycle. Problematic reception of the genre}

\subsection{The French romance of the $19^{\text {th }}$ century. Brief comments}

The choice of the performer to whom the voice and piano version was dedicated, namely Louise Bertin, is a clue to the genre of Les Nuits d'été: the romance. Louise Bertin was the daughter of the director of the Journal des Débats, to whom Berlioz paid tribute. Louise Bertin was trained in FrançoisJoseph Fétis's composition class and, according to the model of other creative women, Sophie Gaïl, Loïsa Puget, Pauline Dechambge, the completion of several chamber opuses and, especially, the acknowledgement of their value by some well-known composers, was the only way to be appreciated in the music world" (Brisson, 2015, p. 2). Playing, at first glance, an ambient role in the salons of that time, Louise Bertin's romances are at the same time an opportunity to highlight a wide range of the most subtle feelings. "Romance, a genre that academics, conservative spirits, tended to despise, criticizing its diminished size, and especially its sentimental expressivity, proved to be a decisive genre for determining musical taste and reception of music, especially in the 1830's" (Brisson, 2015, p. 3). 


\subsection{Les Nuits d'été. General musical traits}

During the first half of the nineteenth century, the French melody faces a crisis of sentimentality, and Hector Berlioz is the composer who rehabilitates this genre. While harmony is not innovative, the present work may be considered a true cycle, due to the value of its chromaticism, which is above all melodic, and due to the care given to the dialogue between voice and orchestra. This is not surprising for the inventor of modern orchestra, for which the timbre combinations have a special meaning. As for the arias in Les Nuits d'été, they musically highlight the prosodic meaning of the text, the composer's ability to bring to light the dramatic aspect of the poem in the absence of any exaggeration. Starting from the aesthetic premises that defined the romantic movement, manifested by the novelty of the concepts in literature, arts, how to feel, live, which were reflected in music, Berlioz is one of the first composers of his time who reached his creative maturity with a kind of fever, of inner turmoil, eager to break all the constraints of Classicism (Sundstrom, 2014, pp. 60-61).

With the completion of the Les Nuits d'été opus, the sequence of six arias reveals its full significance. Berlioz contributes to the melody's value, away from the rigid constraints frame of the opera. Due to their plasticity, Théophile Gauthier's lines in La Comédie de la mort are suitable for receiving musical support. These are Berlioz's first melodies, based on the idea of a cycle, according to the Beethoven lied art principle, where the common denominator is the theme of love for extreme melodies and regrets, under different romantic hypostases, for the other four (Blot, 2013, p.1).

\subsection{Musical-poetic considerations}

\subsubsection{Villanelle ${ }^{53}$}

The origin of the villanelle genre may be traced back to the sixteenth century (1586), more precisely to a song originally accompanied by dancing. By extension, at the beginning of the seventeenth century, the poem has a fixed form, assuming the existence of three-line verses and a refrain ending with a quatrain. As far as themes are concerned, the lines reveal the sensations experienced by a young lover who dreamed to flee into the woods in the company of his beloved. From the architectural point of view, the tripartite strophicity of the poem is observed, each verse being repeated on the same

\footnotetext{
53 The poem Villanelle in French and its translation in English: „Quand viendra la saison nouvelle, Quand auront disparu les froids, Tous les deux nous irons, ma belle, Pour cueillir le muguet aux bois; Sous nos pieds égrenant les perles Que l'on voit au matin trembler, Nous irons écouter les merles Siffler./ Le printemps est venu, ma belle, C'est le mois des amants béni, Et l'oiseau, satinant son aile, Dit des vers au rebord du nid. Oh! viens donc, sur le banc de mousse Pour parler de nos beaux amours, Et dis-moi de ta voix si douce: Toujours!/Loin, bien loin, égarant nos courses, Faisant fuir le lapin caché, Et le daim au miroir des sources Admirant son grand bois penché; Puis chez nous, tout heureux, tout aises, En panier enlaçant nos doigts, Revenons, rapportant des fraises Des bois.." ("When the season revives, When the cold will have disappeared, Both of us, my love, will go, To pick the lilies in the wood; Beneath our feet, will be bursting pearls, Seen quivering in the morning air, When we go to hear the blackbirds, Singing./ Spring has come, my love. It is the month of happy lovers; And the bird, preening its wings, Declaims on high from the nest. Oh! Come to a mossy bank, To tell of our noble love, And speak it in your tender voice, Always./ Far, far off, we will wander away, Setting the rabbits to flight, And see the stag, in the fountain mirror, Admiring his antlers proudly. Then, homeward, rejoicing, all at ease, With fingers linked in the basket, We shall return bringing the berries, Out of the woods”).
} 
melodic lines each time. From a musical point of view, I have noticed that this poem does not distinguish itself by a dramatic progression, but by simplicity, as it has a descriptive nature. Music has no marked vocal independence, and moreover, in the orchestra's register we do not find any sound theme. "It is limited to a pure, regular and fast-paced accompaniment, reminiscent of classical Viennese writing at the end of the eighteenth century and the beginning of the nineteenth century" (Rose et Denizeau, 2004, pp. 4-5). Although each verse is sung on the same vocal lines, some subtle changes in the orchestra may be distinguished from one compartment to the other. We refer, for example, to the beginning of the melody (bars 3-4), in which the voice and the chorus of the string instruments evolve individually, while in the next verse (bars 43-44), the law strings (violas and cellos) resumed and imitate the original motif of the aria (bar 87, where the clarinet is added). The general tone is A Major, but Berlioz sometimes surprises us during the melody by surprising modulations at distant tones: B flat minor (bar 10), C sharp minor (bar 20). It is noteworthy that in Villanelle, the musical texture expresses the freshness and frailty of love; the use of stacatto for wind instruments, the modulation dynamism and the free imitation passages remind us of the dramatic legend of Romeo and Juliet, an opus composed only a few months before.

Figure no. 1, Villanelle, bars 1-18

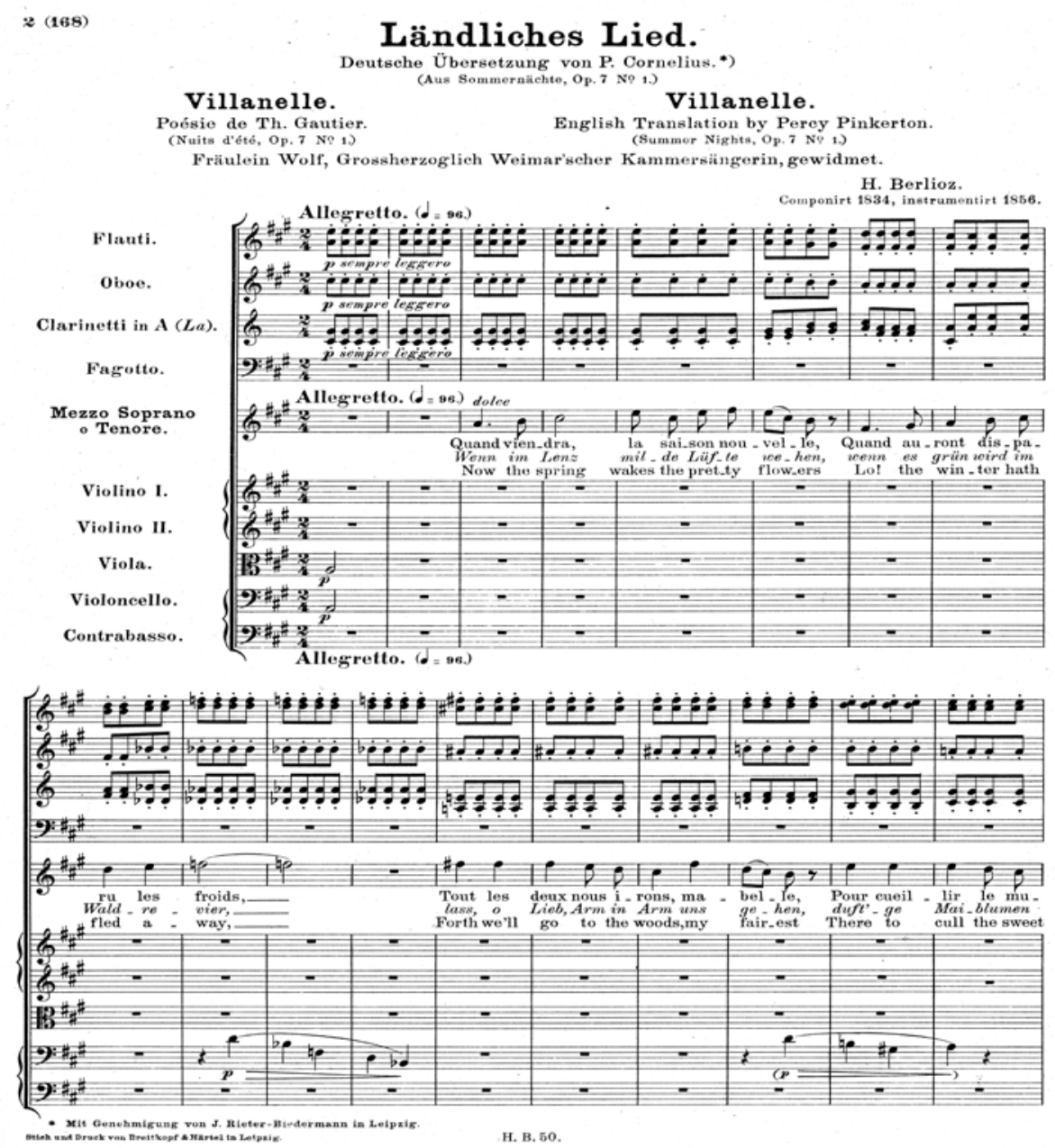




\subsubsection{Le Spectre de la Rose $e^{54}$ (The Ghost of the Rose)}

The theme is fantastic. A rose reappears as a spectre confessing in a low tone its love for the character who accompanied him to a ball. There are some typical romantic motifs: death, love and memory. Like the previous aria, this poem is also devoid of any dramatic progression. Its architecture is stanza-like, creating the impression of continuous recitation in the absence of repetition. We notice that the text plays the main role and subordinates the music. From a musical point of view, we note the lack of unity of the orchestral accompaniment, as each stanza or even each line is accompanied in a different manner, depending on the poetic meaning expressed. As a timbre feature we notice the presence of the harp, with a special coloring role. The sound is bright, a feature highlighted by the D Major tone. In the first bars of the poem, a concentrated introduction brings the theme to the vocal plane, later resumed by the flutes and clarinets, a musical idea that will be redeemed with the beginning of each stanza.

A motif in a dynamic exposure is revealed by the first and second violins, and when the voice is heard, it becomes the central character, enhanced in a continuous discourse. Thus, the impression is that of pressure, due to the nature of the recitative part: slow and calm. Each progression in the text is accompanied by an additional musical dynamism. For example, on the line Et parmi la fête étoilée (And throughout the glittering scene, bar 22), the whole set of string instruments intones quick portrayals. The vocal line corresponds metaphorically to the evocation of the mental connections between two beings, one real and the other imaginary, since the answer is revealing tu me promenas tout le soir (paraded all night was I seen).

At the beginning of the second stanza, the music becomes increasingly dynamic thanks to a new orchestration: the strings in pizzicato on repeated sounds, leading to the main statement of the rose Toutes les nuits mon spectre rose viendra danser (Throughout the night, my ghost of a rose / Will come to dance by your bed, bar 34). The chromatic sliding of the voice and of the orchestra accompaniment on the lines Mais ne crains rien, je ne réclame ni messe ni De profundis (But have no fear, I shall claim / No mass no De Profundis), accentuates the tone of prayer of the rose. There follows a

\footnotetext{
${ }^{54}$ The poem in French and its translation in English: „Soulève ta paupière close Qu'effleure un songe virginal; Je suis le spectre d'une rose Que tu portais hier au bal. Tu me pris, encore emperlée Des pleurs d'argent, de l'arrosoir, Et parmi la fête étoilée Tu me promenas tout le soir. O toi qui de ma mort fus cause, Sans que tu puisses le chasser, Toutes les nuits mon spectre rose A ton chevet viendra danser. Mais ne crains rien, je ne réclame Ni messe ni De profundis: Ce léger parfum est mon âme, Et j'arrive du paradis. Mon destin fut digne d'envie: Et pour avoir un sort si beau, Plus d'un aurait donné sa vie, Car sur ton sein j'ai mon tombeau, Et sur l'albâtre où je repose Un poëte avec un baiser Écrivit: Ci-git une rose, Que tous les rois vont jalouser.("Open your eyelids now closed, That brush on a maidens dream; I am the ghost of the rose, That you wore at the ball last night. You plucked me still silvered with pearls, Sprinkled like tears from the hose, And throughout the glittering scene, Paraded all night was I seen./ O you who have caused my death, Unable to chase it away, Throughout the night, my ghost of a rose, Will come to dance by your bed. But have no fear, I shall claim, No mass nor De Profundis; This faint perfume is my soul, And from paradise do I come./ My destiny may serve for envy; For no better death could one have, Than thus to have given one's life. For, I have your breast as my tomb, And there on the headstone where I repose, A poet has left me a kiss, And written: "Here lies a rose, Of which, kings are inclined to be jealous”).
} 
crescendo, correlated with the text Mon parfum est mon âme (This faint perfume is my soul). As we approach the third stanza, we notice that the original theme is resumed (bar 50). We also note the modulation in the tonality of Et parmi la fête étoilée (bar 58) in accord with the poetic line Et sur l'albâtre... (And there on the headstone...), when the voice holds the main role. The last line Ci git une rose que les rois vont jalouser (Here lies a rose of which kings are inclined to be jealous, bar 62) is sung almost as a declamation (on the rhythm of the words), very slowly, accompanied solely by the sound of the clarinet (Rose and Denizeau, 2004, pp. 6-7).

Figure no 2 Le Spectre de la Rose, bars 1-4

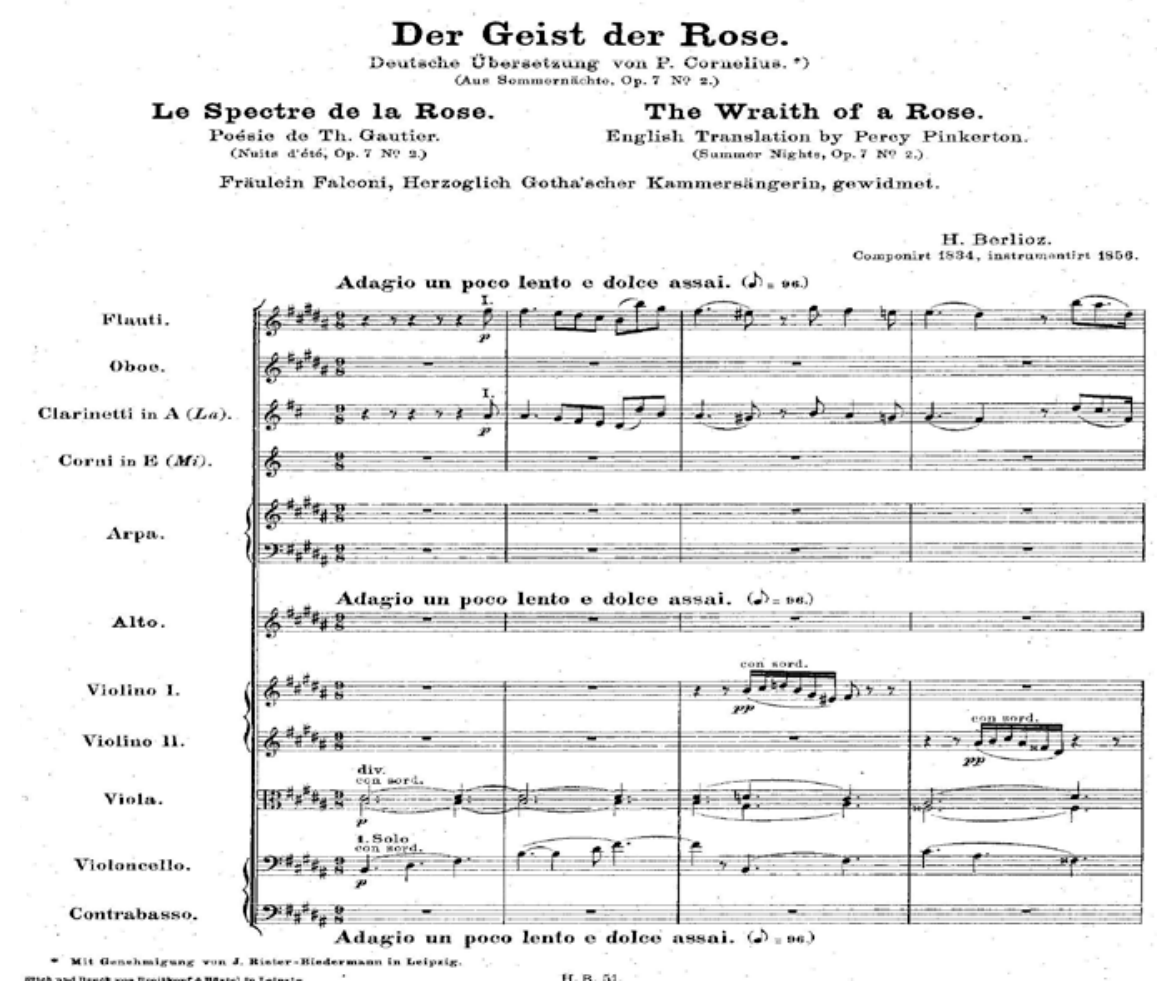

\subsubsection{Sur les lagunes ${ }^{55}$ (On the Lagoons)}

The themes focus on a character lamenting for the disappearance of his beloved. The themes evoked are: loneliness, night, love. The text renders the

\footnotetext{
55 The poem in French and its translation in English: „Ma belle amie est morte: Je pleurerai toujours Sous la tombe elle emporte Mon âme et mes amours. Dans le ciel, sans m'attendre, Elle se retourna;L'ange qui l'emmena Ne voulut pas me prendre. Que mon sort est amer! Ah! sans amour s'en aller sur la mer! La blanche créature Est couchée au cercueil. Comme dans la nature Tout me paraît en deuil! La colombe oubliée Pleure et songe à l'absent; Mon âme pleure et sent Qu'elle est dépareillée! Que mon sort est amer! Ah! sans amour s'en aller sur la mer! Sur moi la nuit immense S'étend comme un linceul; Je chante ma romance Que le ciel entend seul. Ah! comme elle était belle Et comme je l'aimais! Je n'aimerai jamais Une femme autant qu'elle. Que mon sort est amer! Ah! Sans amour s'en aller sur la mer! (Dead is my beloved: And I shall weep for ever; In the tomb where she is buried, My soul and love lie with her. To heaven has she returned, But not for me has waited, It was for her that angels yearned, And not I whom they had wanted. Ah! Life without love is to me, The bitterest fate on the sea./ That pale creature, In her coffin is laid; With the whole of nature, In mourning arrayed. The dove that has been forsaken, Laments in dreams her absence. My weeping soul has sensed, That her link to us is broken. Ah! Life without love is to me, The bitterest fate on the sea./ The immensity of night, Spreads like a shroud about me; My romance I chant, But am heard by heaven only. Ah! Such beauty had she! And how I loved her! I shall not love another, When I have loved so deeply. Ah! Life without love is to me, The bitterest fate on the sea!”).
} 
evolution of a psychological state rather than that of a dramatic progression. The three broad sections correspond to the three stanzas, but their refrains have the same motif - Ah! sans amour s'en aller sur la mer (Ah! Life without love is to me / The bitterest fate on the sea!, bar 20). But with the exception of the line containing the refrain, the general construction does not obviously justify the existence of the three parts.

From a sound point of view, in accordance with the content of the text, music has a slow and bleak expressiveness. The annihilation of the main character is particularly emphasized by this special Lamento chant. Each refrain is highlighted by a long note, preceded by a plagal tempo (fourth step in C minor, in the general context of $\mathrm{G}$ minor key) in relation to the edifying tine: Que mon sort est amer (Ah! Life without love is to me / The bitterest fate on the sea!, bars 30-70-102). Due to the minor mode ( $\mathrm{G}$ minor) and the very slow tempo, the first part develops a sound environment conducive to the desolation of the protagonist. The slowness of the tempo is properly associated with the evening service atmosphere.

The privileged moments of romantics, night and loneliness, allow them to get in touch with their inner self away from the wild world. Unlike the first part which is very slow, the central section is more animated, because it directly evokes the soul of the beloved: La blanche créature est couchée, Est couchée au cercueil. (That pale creature / In her coffin is laid). This animation is marked by a more vibrant pulse of the orchestra (exposing a fast motif by double strings, bar 54, La colombe oubliée ... The dove that has been forsaken) and reaches the climax in the lines Mon âme pleure et sent qu'elle est dépareillée, (My weeping soul has sensed / That her link to us is broken!, bar 61).

This is undoubtedly the composer's way of creating suspense, anxiety. This paroxysm translates to the sound environment by the appassionato indication (bar 61) and the virtuosity of some sound figures among the woodwind instruments. The second part impresses by its writing in unison, which has a glacial effect, as the text is impregnated with the desperation of the main character whose beloved is dead and nothing can bring her back to life. The third section distinguishes itself by the $G$ minor / G Major / G minor, modal oscillation, the protagonist culminating in the vocal plane with the expression of a funeral lament: Que mon sort est amer (Ah! Life without love is to me / The bitterest fate on the sea!). The coda extends the refrain motif of each part, the composer and poet collaborates brilliantly to highlight the particularly sensitive relationship between text and sound. The $A h$ exclamation corresponds to the barely whispered intonation of the string instruments, the final chord being that of the dominant (major), metaphorically causing the last doubt: is this really the end or are there other events? (Rose and Denizeau, 2004, pp. 9-11). 
Figure no. 3, Sur les lagunes, bars 1-6

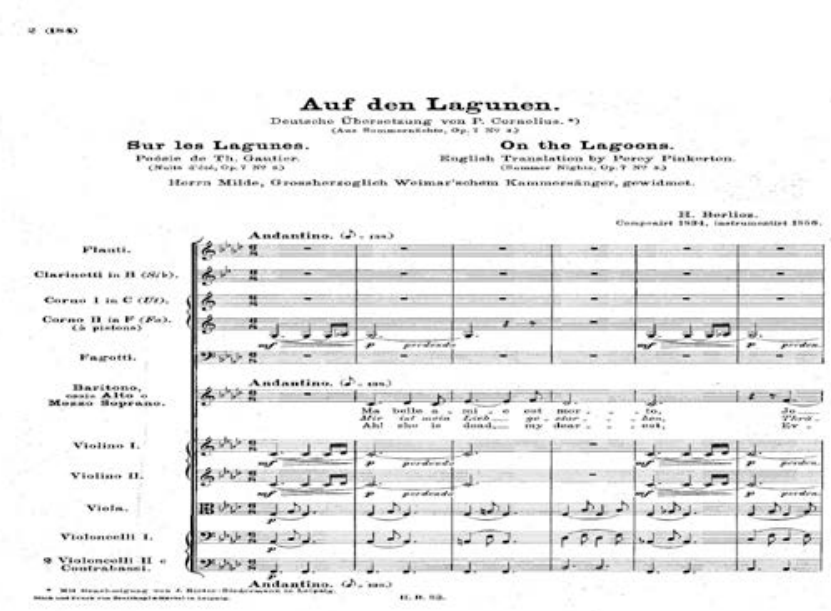

\subsubsection{Absence $^{56}$ (Absence)}

The theme focuses on the lover who laments for the departure of his beloved. Love, frustration, attention, travel are the main topics. From an architectural point of view, the poem is built around a refrain stanza repeated three times, with two verses inserted between them. At the musical level, the aria is characterized by its concise size and reduced orchestration, to support a simple and concise poem. It is undoubtedly the least demonstrative aria of the whole cycle. We are not faced with the same tragic expressivity of the previous melody. Moreover, the idea of hope is contrived by the very choice of the tonal option of the musician: F sharp major.

The refrains of the texts have the same sound characterized by moments of pause corresponding to the line: Reviens reviens, ma bien aimée (Return, return my beloved!). These silences, moments of suspense, can be interpreted as sound illustrations of the narrator's painful expectation. The orchestra only intervenes to emphasize the main melody (first violins) or to support the theme on several long notes. The beginning of the first verse stanza is simplified in terms of accompaniment and the music becomes more dynamic along the way through sounds repeated by the string instruments or through a vocal, $O$ dure absence (Oh, harsh absence, bar 20). Yet, the character returns to the original state of lament accompanied by silence. This is a pattern that is to be found also in the following stanza: the sound dynamics corresponds to the line: A lasser le pied des chevaux, bar 49 (Rose and Denizeau, 2004, p. 11).

\footnotetext{
${ }^{56}$ The original poem and its translation in English: „Reviens, reviens, ma bien-aimée! Comme une fleur loin du soleil, La fleur de ma vie est fermée Loin de ton sourire vermeil. Entre nos cœurs quelle distance! Tant d'espace entre nos baisers! O sort amer! ô dure absence! O grands désirs inapaisés! Reviens, reviens, ma belle aimée! Comme une fleur loin du soleil, La fleur de ma vie est fermée Loin de ton sourire vermeil! D'ici là-bas que de campagnes, Que de villes et de hameaux, Que de vallons et de montagnes, A lasser le pied des chevaux! Reviens, reviens, ma belle aimée! Comme une fleur loin du soleil, La fleur de ma vie est fermée Loin de ton sourire vermeil! (Return, return my beloved! Like a flower far from the sun, The flower of my life is closed, Far from your rosy smile./ Between our hearts, so much distance! So much space between our kisses! Oh, bitter fate! Oh, harsh absence! Oh, great desires unrequited!/ Return, return my beloved! Like a flower far from the sun, The flower of my life is closed, Far from your rosy smile./ From here to there, too vast the country, Where towns and hamlets, Valleys and mountains, Tire even the tramp of horses./ Return, return my beloved! Like a flower far from the sun, The flower of my life is closed, Far from your rosy smile!”).
} 


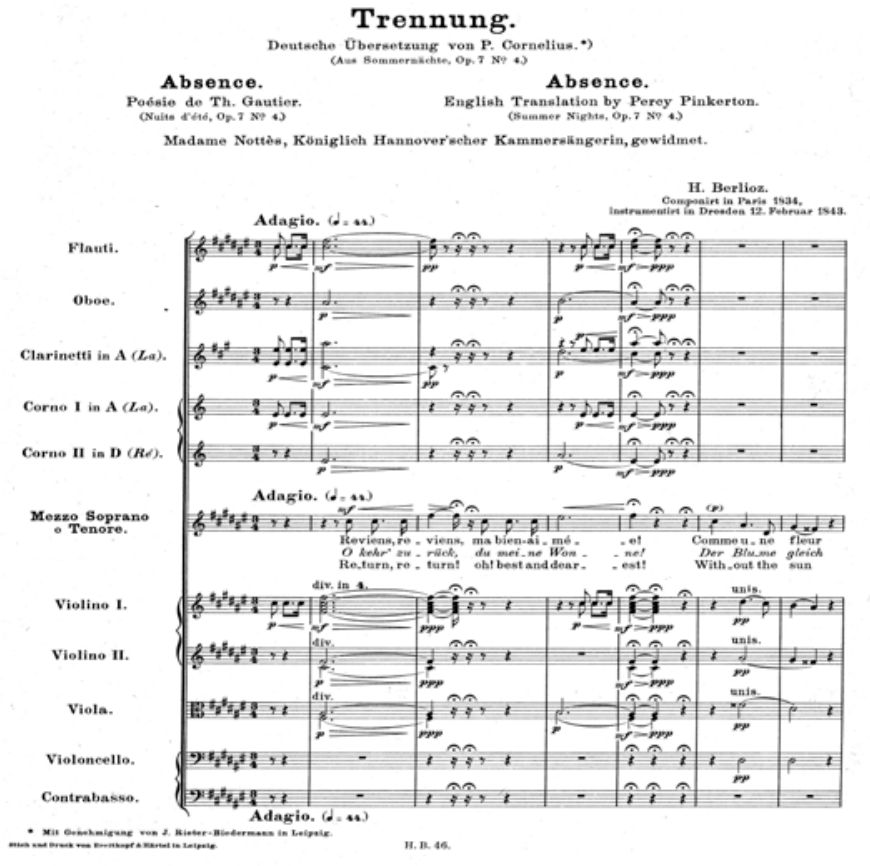

\subsubsection{Au cimetière ${ }^{57}$ (Clair de lune)- At the Cemetery (Moonlight Lament)}

The themes revolve around another fantastic subject, where the narrator, attracted by the song of a dove, notices with fear the illusory return of the ghosts beyond the grave. After the frightening vision of the l'ombre au voile blanc (shadow veiled in white) and of the spirit of aux molles poses (quiet rest), the protagonist swears that he will not be attracted again by the song of the dove. Thematic ideas focus on death, fantastic creatures, frightfulness. As a matter of fact, the theme of the cemetery has already been evoked in the third aria, Sur les lagunes. The Claire de lune subtitle is an undeniable sign of early Romanticism: the twilight images of the night fascinate the creators of the nineteenth century. $\mathrm{Au}$ cimetiere is one of the most meaningful arias of the entire cycle. At the formal level, $\mathrm{Au}$ cimetière is the first poem of the cycle that has a dramatic

\footnotetext{
${ }^{57}$ The poem in French and its translation in English „Connaissez-vous la blanche tombe Où flotte avec un son plaintif L'ombre d'un if? Sur l'if une pâle colombe Triste et seule au soleil couchant, Chante son chant;Un air maladivement tendre, A la fois charmant et fatal, Qui vous fait mal, E qu'on voudrait toujours entendre; Un air comme en soupire aux cieux L'ange amoureux. On dirait que l'âme éveillée Pleure sous terre à l'unisson De la chanson, Et du malheur d'être oubliée Se plaint dans un roucoulement Bien doucement.Sur les ailes de la musique On sent lentement revenir Un souvenir; Une ombre une forme angélique Passe dans un rayon tremblant, En voile blanc. Les belles de nuit, demi closes, Jettent leur parfum faible et doux Autour de vous, Et la fantôme aux molles poses Murmure en vous tendant les bras: Tu reviendras? Oh! Jamais plus, près de la tombe Je n'irai, quand descend le soir Au manteau noir, Écouter la pâle colombe Chanter sur la pointe de l'if Son chant plaintif! (Do you know that tomb of white, Where, with plaintive sound, The shadow of a yew is floating? A pale white dove upon the yew, Alone to the setting sun, Sadly sings his song./ An air so bittersweet, Both charming and resigned, That one disquiets, But would always wish to hear; An air like a sigh in heaven, From an angel's loving./ One would say that the soul would waken, To weep beneath the earth in concord, With that song And from the plight of being forsaken, Croon despair in gentle moaning, Whilst intoning./ On the wings of music born, One feels remembrance Returning slowly; A shadow in angelic form, Passes in a shimmering light, Veiled in white./ The half closed night time beauties, Spread their perfume faint and sweetly, Round you, And the spirit of quiet rest, Murmurs to you with outstretched arms: "You will return"./ Oh! Never more near that grave, Shall I go when evening falls, With sabled shawl, To hear that pale white dove, Sing in that branch of yew, Its plaintive song.“).
} 
progression. There is a beginning (attraction through the song of the dove), a middle section (appearance of the spirit) and a final section (the flight of the dove and the narrator's desire not to return to this place). Therefore, one may notice here three-stanza structure of the ABA type.

From the music point of view, we should first note the reduced orchestration: flutes, clarinets and strings. The first two stanzas, the role of which is to set the scenery, are highlighted temporally by the symmetrical threestroke measure. Although the main key is D Major, the feature of the aria is tierce modulation: (D minor- F sharp minor - A minor; B flat minor - D minor F minor), in relation to the character's mood swings. It is worth mentioning the orchestral emphasis of the bleak atmosphere in a manner specific to Berlioz: ostinato structures for the string instruments, tremolo effects for the cellos, the voice supported by the clarinet in the acute register (in the dissonant rendering of certain thematic fragments at $\mathrm{F}$ sharp/G semitone distance). These practices bring us back to familiar musical moments like the March to the Scaffold of the Dream of the Night of the Sabbath in the Fantastical Symphony, composed during the same period (Rose and Denizeau, 2004, pp. 14-16).

Figure no. 5, Au cimetière, bars 1-20

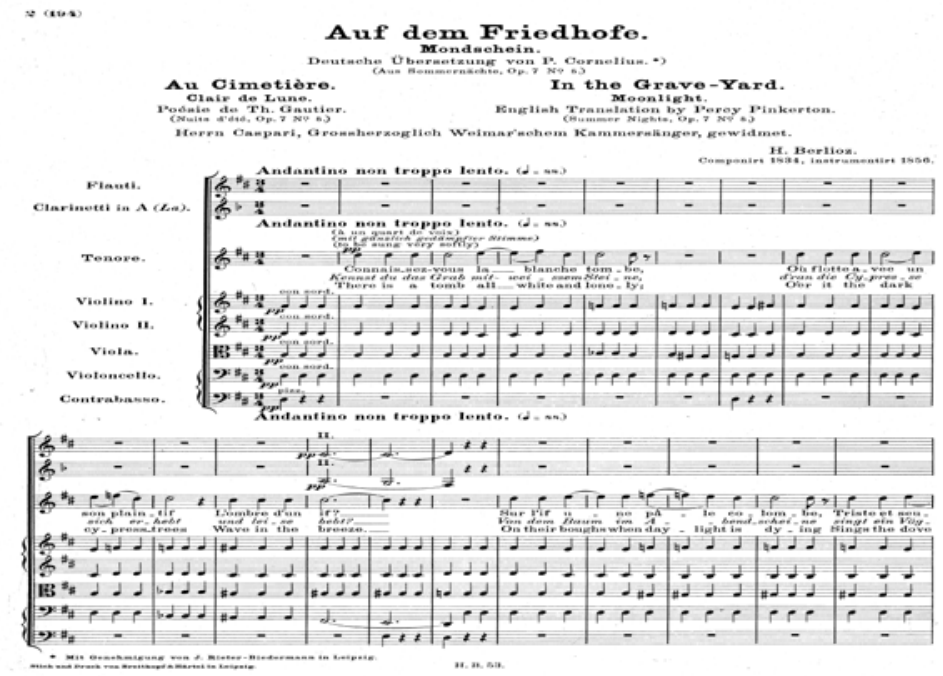

\subsubsection{L'Île Inconnue ${ }^{58}$ (The Unknown Island)}

The poem is conceived as questions addressed to a young girl. The themes revolve around typical romantic issues: from exotic places and traveling, to

\footnotetext{
${ }^{58}$ The original poem and its translation into English:,, Dites, la jeune belle, Où voulez-vous aller? La voile enfle son aile, La brise va souffler. L'aviron est d'ivoire, Le pavillon de moire, Le gouvernail d'or fin; J'ai pour lest une orange, Pour voile une aile d'ange, Pour mousse un séraphin. Dites, la jeune belle, Où voulez-vous aller? La voile enfle son aile, La brise va souffler. Est-ce dans la Baltique? Dans la mer Pacifique? Dans l'île de Java? Ou bien est-ce en Norvège, Cueillir la fleur de neige, Ou la fleur a'Angsoka? Dites, dites, la jeune belle, dites, où voulez-vous aller? Menez moi, dit la belle, A la rive fidèle Où l'on aime toujours! Cette rive, ma chère, On ne la connaît guère Au pays des amours. Où voulez-vous aller? La brise va souffler.( Tell me, my beauty, Where are you going? The sail opens its wing, And the breeze is blowing./ The oar is of ivory, The awning of moiré, The helm of finest gold; For ballast I have an orange, For a sail, an angel's wing, For ship boy, a seraph./ Tell me, my beauty, Where are you going? The sail opens its wing, And the breeze is blowing./ Is it to the Baltic, To the wide Pacific, Or to the isle of Java? Or perhaps to Norway, To pluck the flowers from snow, Or the flower of Angsoka ?/ Tell me, my beauty, Where are you going? The sail opens its wing, And the breeze is blowing./ Take me, said the beauty, To the banks where truly, Love will always be. That bank, my dear, So little known, In the land where love is free").
} 
adventure, youth and love. Generally speaking, the architecture is of the refrainverse type, yet the chorus music is not fully quoted with each occurrence of it. From the music point of view, in the context of the whole cycle, this aria is completely different. The orchestration is much broader and relies on the intonation of the horns. Unlike the static effect and the monotonous ambiance specific to the $2^{\text {nd }}$ and $4^{\text {th }}$ arias (underlying the literary ideas of abandonment, desolation, death), in this poetic-musical context, one is surprised by the dynamism of all the language parameters. In this respect, the compositional option for bar $6 / 8$ is decisive.

The center of the key is $\mathrm{F}$ major, but Berlioz chooses the fifth step chord for the harmonic structure at the beginning of the aria (C Major dominant), vesting the first four bars with the introductory role that prepares the vocal exposition. A subtle $\mathrm{F}$ minor inflection, followed by a few modulations on distant keys, is in agreement with the poetic idea La voile enfle son aile, la brise va souffler (The sail opens its wing, And the breeze is blowing.). Finally, the beautiful young woman stops dreaming and voices a new idea (bar 84). She is less interested in exotic lands, as she prefers la rive fidèle où l'on aime toujours (to the banks where truly, Love will always be), since cette rive (...) on ne la connaît guère au pays des amours (that bank (...) so little known, in the land where love is free). From a musical point of view, the aria ends in the same triple meter, in a diminuendo of the voice and instruments that gently support sonority (Rose and Denizeau, 2004, pp. 18-20).

Figure no. 6, L'Île Inconnue, bars 1-5

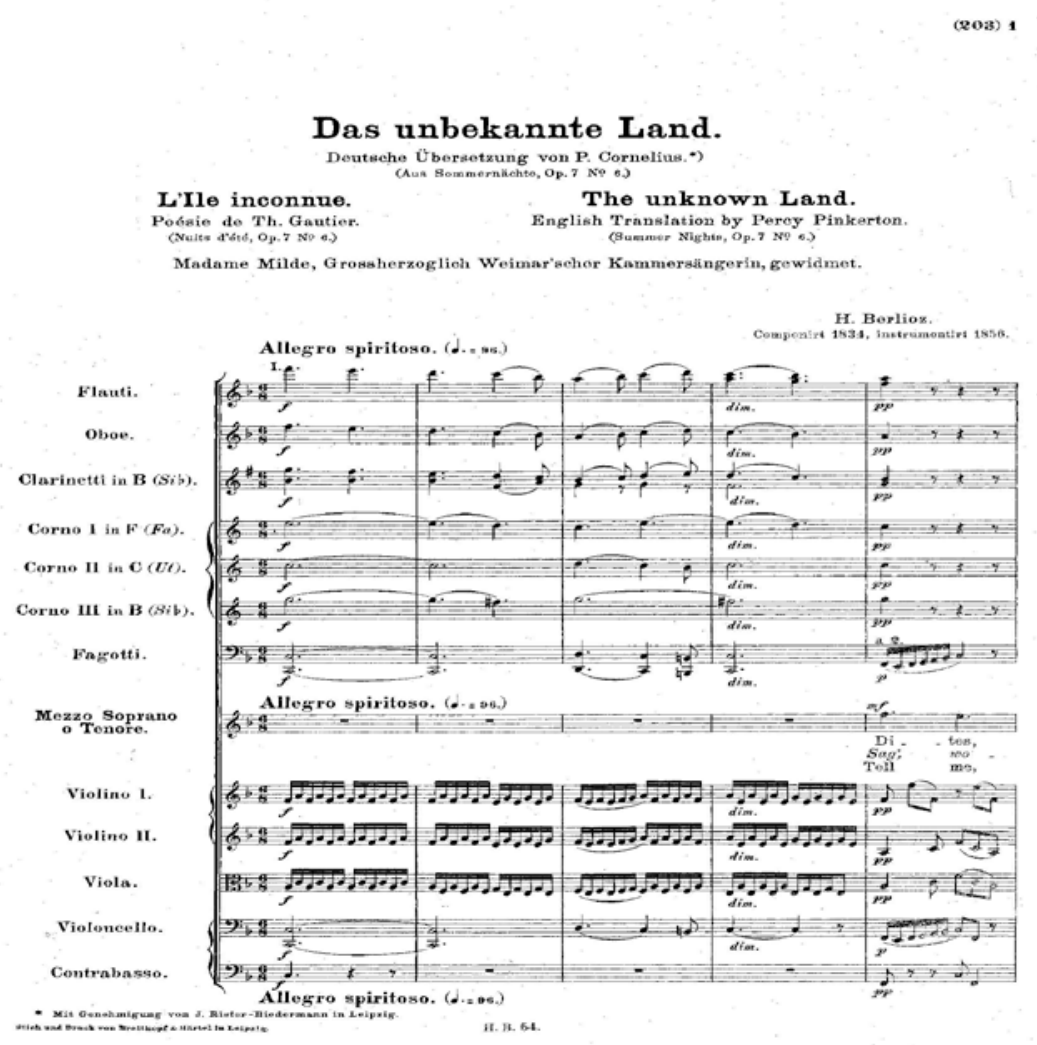




\section{Conclusions}

After I have read the references and the musical score for this opus, I came to the conclusion that the arias belonging to the Les Nuits d'été cycle are a valuable creation, the importance of which was largely acclaimed in the second half of the twentieth century. The contradictory comments of musicologists about the perception of the opus as a cycle or collection hypothesis were further proof of the interest raised by this work, due to the unprecedented correspondence of the text-sound relationship. The reception of the arias included in the Les Nuits d'été cycle may only be done in the light of Th. Gautier's poetic metaphors, with the sound symbols enciphered by Hector Berlioz in his music. Moreover, the reading of the philosophical texts from $L a$ Comédie de la mort highlights Th. Gautier's preoccupations, which go beyond the general framework of Romanticism and approach Symbolism, thus anticipating the freeing of poetry of the traditional approaches to its structure and poetical meanings.

Berlioz the creator, the relentless seeker of harmonic melodic structures and of unusual orchestral combinations, grasped the poetic value of Gautier's poetry and, in particular, in agreement with the particular sound of each lied, and he contributed to the revival of the genre of romance, which, in his view, becomes an elevated music, relevant from the perspective of all language parameters. Also, embellishing the genre of the melody, he lays the foundations of orchestral lied of philosophical poetic inspiration, which will be illustrated in a magnificent way by Gustav Mahler a few decades later.

What was the purpose of this work? How do we explain the completion of an opus for voice and piano which the musician changes a few years later? Let us not forget that we refer to the creator dedicated to the dramatic symphonic genre, inclined to far-reaching sonorities and, above all, with an explosive temper. He was the artist, the composer, the critic, the conductor, the concert organizer who wanted to impress, to shock the audience and especially to prove to the artistic authorities of his time that music needed a change.

In his study, musicologist Peter Bloom commented on the completion of the opus in the light of a series of biographical motivations, claiming that the romantic artist "wanted to incorporate in the music of his arias either the deep emotions of farewell to his wife, Harriet Smithson, who until 1840 became more and more dependent, isolated, predisposed to illness, sensitive, frustrated, resentful, or the sonorous illustration of his new feelings for Marie Recio" (Bloom, 2016, p. 90). Now, the explanation should be sought at the creative level in the case of the musician who had known fame thanks to an opus like the Fantastical Symphony and who felt the need to focus his creative energy on the fundamental element of his compositional universe, the melody, which he intended to use pure, in order to highlight its expressive latencies. In this manner, Hector Berlioz focused on the symbolic dimension of intrinsic meanings deduced from the text-sound correspondences, giving up for the moment the descriptive programmatism of the developing orchestral pages. 
As we near the end, we only want to express some thoughts about the enigmatic title. In this respect, we focused on Élisabeth Brisson's considerations, according to whom the metaphor may only be deciphered if correlations are made with the texts of some important poets of that time like V. Hugo, W. Shakespeare or W. Goethe. The title Les Nuits d'été, says the quoted author, "is the result of a shifting and condensation of meaning to translate what is hidden in the depths of his being, and which can only be expressed through a specific musical approach, by imperceptibly leaving the real world and entering the realm of fantasy" (Brisson, 2015, p. 5). These aesthetic-philosophical considerations enable us to understand the dynamism of one of the refined concepts of the nineteenth century, the romantic irony, revealed in the present case, by transferring the ambiguity of meaning specific to Th. Gautier's poems included in the La Comédie de la mort cycle to Hector Berlioz's mysterious melody cycle, metaphorically entitled Les Nuits d'été.

\section{Bibliography}

1. Blot, A. (2013). Article Les Nuits d'été six mélodies op. 7, în: www.opmc.mc/les-nuits-dete-six-melodies-opus-7/, pp.1-2

2. Bloom, P. (2016). In the shadows of Les Nuits d'été, chapter 4, în: Berlioz Studies, Cambridge Books Online, Edited by Peter Bloom, Cambridge University Press, Online ISBN: 9780511551420, http://ebooks.cambridge.org/, pp. 80-111

3. Brisson, É. (2015). Article Les Nuits d'été - Enquête sur un titre, în: https://www.leducation-musicale.com> ARTICLES, pp. 1-10

4. Denizeau, G. et Rose, C. (2004). L'Education Musicale septembre/Octobre

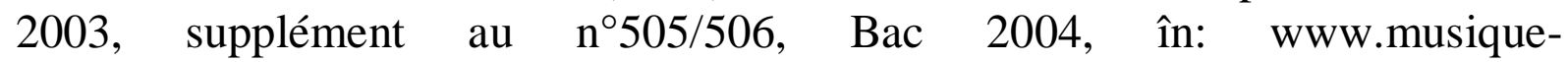
millet.com/...nuits_d_ete_berlioz/option_facultative, pp. 1-20

5. Holoman, D Kern (1989). Berlioz, Harvard University Press. ISBN 978-0674-06778-3, pp.1-704

6. Nicolescu, M. (1964). Berlioz viaţa unui compozitor romantic, ediţia a II-a, Editura Muzicală a Uniunii Compozitorilor din R.P. R., pp.1-214

7. Pourtalès, de G. (1979). Berlioz şi Europa romantică, traducere de Annie Bentoiu, Editura Muzicală, pp. 1-357.

8. Rushton, J. (2016). Les Nuits d'été: cycle or collection?, chapter 5, în: Berlioz Studies, Cambridge Books Online, Edited by Peter Bloom, Cambridge University Press, Online ISBN: 9780511551420, http://ebooks.cambridge.org/, pp. 112-135

9. Sundstrom, A. K.(2014). Berlioz's Les Nuits d'été: Masterful Orchestration as a Vehicule for Text Expression, Honors Thesis Collection, Wellesley College Digital Scholarship and Archive, Advisor: Gurminder K. Bhogal, Music, pp. 165 